\title{
Prevalence of prognostic factors for cancer of the uterine cervix after radical hysterectomy
}

\author{
Prevalência de fatores prognósticos em câncer de colo uterino após histerectomia radical \\ Marília Buenos Aires Cabral Tavares ${ }^{1}$, Rodrigo Beserra Sousa² ${ }^{2}$ Thiago Oliveira e Silva², Larissa Almeida Moreira ${ }^{3}$, \\ Loyana Teresa Teófilo Lima Silva ${ }^{3}$, Carolina Buenos Aires Cabral Tavares ${ }^{4}$, Sabas Carlos Vieira ${ }^{5}$ \\ Hospital São Marcos and Universidade Federal do Piauí, Teresina, Piauí, Brazil
}

\section{Key words:}

Survival analysis.

Cervix uteri.

Uterine neoplasms.

Hysterectomy.

Gynecologic surgical procedures.

\section{PALAVRAS-CHAVE:}

Análise de sobrevida.

Colo do útero.

Neoplasias uterinas.

Histerectomia.

Procedimentos cirúrgicos em ginecologia.

\begin{abstract}
CONTEXT AND Objective: Cancer of the uterine cervix is still very common in Brazil. It is important to evaluate factors that influence its prognosis. The aim here was to analyze the prevalence of prognostic anatomoclinical factors among patients with carcinoma of the uterine cervix undergoing radical hysterectomy.

DESIGN AND SETIING: Cross-sectional study on 301 patients with invasive carcinoma of the uterine cervix who underwent Level III Piver-Rutledge hysterectomy surgery at São Marcos Hospital.

METHODS: The following variables were analyzed: age, histological type, degree of differentiation, invasion of lymphatic, vascular and perineural space, lymph node metastasis, distance to nearest margin, tumor invasion depth, vaginal cuff size, largest diameter of the tumor, presence of necrosis and surgical margin involvement. Descriptive statistics, multiple regression analysis, Kaplan-Meier survival curves and the log-rank test were performed. A significance level of $5 \%$ was used.

RESULTS: The mean age was 48.27 years. The following were not important for the prognosis, in relation to survival analysis: degree of differentiation and tumor invasion depth; presence of lymphatic, blood and perineural invasions; distance to nearest margin; and vaginal cuff size. Tumor size $(P<0.036)$, presence of lymph node metastasis $(P<0.0004)$, necrosis $(P<0.05)$ and surgical margin involvement $(P<0.0015)$ presented impacts on survival. The overall survival with 98 months of follow-up was $88.35 \%$.

CONCLUSION: The most prevalent prognostic factors were the presence of lymph node metastasis, tumor size and surgical margin involvement.
\end{abstract}

\section{RESUMO}

CONTEXTO E OBJETIVO: 0 câncer do colo do útero é ainda muito frequente no Brasil, sendo importante avaliar os fatores que influenciam no seu prognóstico. 0 objetivo é analisar a prevalência dos fatores prognósticos anatomoclínicos em pacientes com carcinoma do colo uterino submetidas a histerectomia radical.

TIPO DE ESTUDO E LOCAL: Estudo retrospectivo de 301 pacientes com carcinoma invasivo de colo uterino submetidas a histerectomia radical nível III de Piver-Rutledge no Hospital São Marcos.

MÉTODOS: Analisaram-se as variáveis: idade, tipo histológico, grau de diferenciação, invasão do espaço linfático, vascular e perineural, metástase linfonodal, distância da margem mais próxima, profundidade de invasão do tumor, tamanho do manguito vaginal, maior diâmetro do tumor, presença de necrose, comprometimento de margens cirúrgicas. Realizou-se estatística descritiva, análise de regressão múltipla, curva de sobrevida pelo método de Kaplan-Meier e teste log rank. Adotou-se índice de significância de 5\%.

RESULTADOS: A idade média foi de 48,27 anos. A análise da sobrevida em relação ao grau de diferenciação e profundidade de invasão do tumor, à presença de invasões linfática, sanguínea e perineural, à distância da margem mais próxima e ao tamanho do manguito vaginal não foram importantes no prognóstico. 0 tamanho do tumor $(P<0,036)$, presença de metástase linfonodal $(P<0,0004)$, necrose $(P<0,05)$ e comprometimento de margens cirúrgicas $(P<0,0015)$ apresentaram impacto na sobrevida. A sobrevida global com um acompanhamento de 98 meses foi de $88,35 \%$.

CONCLUSÃO: Os fatores prognósticos mais prevalentes foram a presença de metástase linfonodal, o tamanho do tumor, a presença de necrose e 0 comprometimento das margens cirúrgicas.
${ }^{1}$ MD. General Surgery Resident, Hospital Universitário Walter Cantídio (HUWC), Universidade Federal do Ceará, Fortaleza, Ceará, Brazil. ${ }^{2}$ Medical student, School of Medicine, Universidade Federal do Piauí (UFPI), Teresina, Piauí, Brazil.

${ }^{3}$ MD. Trained at Universidade Federal do Piauí (UFPI), Teresina, Piauí, Brazil.

${ }^{4} \mathrm{MD}$. Gynecologist and Obstetrician, Maternidade-Escola Assis Chateaubriand (MEAC), Universidade Federal do Ceará (UFC), Fortaleza, Ceará, Brazil. ${ }^{5} \mathrm{MD}$, PhD. Oncological Surgeon and Professor, Universidade Federal do Piauí (UFPI), Teresina, Piauí, Brazil. 


\section{INTRODUCTION}

Cervical cancer is a serious public health issue in Latin America. In Brazil, it is the third most common malignant type of cancer among women, only surpassed by skin cancer (non-melanoma) and breast cancer. Moreover, it is the greatest cause of death among the female population of reproductive age. This type of cancer represents $10-15 \%$ of all malignant tumors in women. ${ }^{1,2}$ In the State of Piauí, Brazil, cervical cancer is ranked second to skin cancer (non-melanoma), among the most frequent types of cancer affecting women. ${ }^{3,4}$ In 2004, this state and its capital presented an increasing trend of mortality due to cervical cancer among the age group of 20 years and over, following regional behavior in this respect. Brazil showed stable rate trends. ${ }^{3,4}$

The treatment of choice for invasive cervical cancer in the initial stages, i.e. stages Ib1 and Ib2 of the International Federation of Gynecology and Obstetrics (FIGO), is radiotherapy or radical hysterectomy with pelvic bilateral lymphadenectomy. Surgery is preferable among young patients because of the possibilities of ovary preservation, hormonal function maintenance and better sexual performance. ${ }^{5}$ Anatomopathological evaluation of the surgical specimen after radical hysterectomy makes it possible to determine prognostic factors that define whether complementary therapy is needed. ${ }^{6-16}$

Patients with large tumors in stages Ib and IIa have a greater tendency towards lymph node metastasis and shorter survival, regardless of whether treated by radical hysterectomy or by radiotherapy. ${ }^{8,9}$ There is greater incidence of lymph node metastasis in the presence of deep stromal invasion, along with smaller rates of two-year disease-free survival (58\% versus $8 \%$ ), than among patients without stromal invasions and with negative pelvic lymph nodes. ${ }^{6,17}$ The presence of positive lymph nodes per se decreases disease-free survival considerably, falling from $80.4 \%$ when there is no lymph node involvement to $60.4 \%$ when there are three compromised lymph nodes and to $45.9 \%$ among patients with four or more compromised lymph nodes. ${ }^{6}$

However, the prognosis is also affected by the histological type, degree of cell differentiation and other patient-related factors. Adenocarcinoma is considered to have the worst prognosis. Tumor size, vascular and lymph node involvement, depth of invasion, parametrial invasion, surgical margin involvement, age group, histological type and degree of tumor differentiation are factors that can also influence the prognosis. ${ }^{6,7}$

\section{OBJECTIVES}

The objective of the present study was to analyze the prevalence of prognostic anatomoclinical factors among patients with uterine carcinoma undergoing radical hysterectomy.

\section{METHODS}

In this investigation, a convenience sample was used, consisting of 301 patients with cervical cancer in FIGO stages I and II who underwent radical hysterectomy at São Marcos Hospital, carried out by the same surgeon (Vieira SC), between July 1999 and July 2006. All of the patients underwent the same surgical procedure: Level III Piver-Rut- ledge hysterectomy, with bilateral pelvic lymphadenectomy. The inclusion criteria were: age less than 45 years, regular menstrual cycles, absence of hypoestrogenism symptoms (heat waves or vaginal dryness) and macroscopically normal ovaries as observed during the surgery. Our institution's Ethics Committee approved the investigation.

The surgical procedure consisted of laparotomy with a medial or upper transverse pubic incision. Level III Piver-Rutledge hysterectomy was performed, with linking of the origin of the uterine artery and parametrium, followed by colpectomy. Bilateral pelvic lymphadenectomy was performed with the following boundaries: crossing of the urethra with the iliac vessels (upper limit); psoas muscles (sides); urethra (medial limit); obturator nerve (back); and origin of the circumflex artery in the iliac artery (lower limit). The pelvic peritoneum was left open, and all the patients received pelvic drainage using a vacuum suction drain with the external counteraperture at the abdominal cavity. Prophylaxis with antibiotics (cefazoline; $1 \mathrm{~g}$ every three hours) was administered, from the time when anesthesia was induced. All the patients received subcutaneous heparin as prophylaxis for deep vein thrombosis. Postoperative radiotherapy was indicated in cases of presence of compromised lymph nodes, compromised vaginal margins or margins of less than $0.5 \mathrm{~cm}$ and parametrial involvement.

The ovaries of 59 patients were preserved. Verbal consent concerning ovary preservation was sought. The preserved ovaries were held at the parietal-colic gutter, homolateral to the level of bifurcation of the aorta, and were clipped with metal clamps, while always observing whether the vascular ovarian pedicle was correctly positioned, in order to avoid torsion and/or traction.

The patients were followed up every four months, over the first two years, and then every six months, from the second to the fifth year. The routine included speculum examination, digital rectal examination and onco-cytological tests on material collected from the vaginal dome. In the presence of specific symptoms, tests were ordered in accordance with the patients' clinical symptoms.

The following variables were analyzed: age group, histological type, lymph node space invasion, vaginal cuff size, largest diameter of the tumor, presence of necrosis and surgical margin involvement (when parietal involvement was found).

The Winstat ${ }^{\circledR}$ software was used to perform descriptive statistical analysis, multiple regression analysis to determine the importance of prognostic factors, Kaplan-Meier survival curve analysis and the logrank test. A significance level of 5\% was used.

\section{RESULTS}

The patients' mean age was 48.27 years, with a range from 25 to 83 years. The mean length of follow-up was 24.57 months, with a range from 0.3 to 98 months. The mean depth of invasion was $1.54 \mathrm{~cm}$. The mean vaginal cuff size was $1.28 \mathrm{~cm}$. The mean distance to the closest margin was $0.83 \mathrm{~cm}$. Fifty-nine patients (19.6\%) of the study group had at least one preserved ovary. The most frequent histological type was squamous cell carcinoma. Undifferentiated tumors were more frequent. In most cases, there was no blood, lymphatic or neural invasion from the tumor. Furthermore, in most cases, there was no lymph node metastasis or surgical margin involvement. Necrosis was usually present in cases with neoplasia (Table 1). 
The patients' ages, degree of differentiation, tumor invasion depth, presence of blood, lymphatic and neural invasion from the tumor, distance to the nearest margin and vaginal cuff size were not important for the prognosis. The largest diameter of the tumor $(\mathrm{P}<0.04)$, presence of lymph node metastasis $(\mathrm{P}<0.01)$, necrosis $(\mathrm{P}<0.05)$ and surgical margin involvement $(\mathrm{P}<0.01)$ presented impacts on the patients' survival rate (Table 2). Graph 1 shows the overall survival (involving all the patients in the study) with a follow-up of 98 months was $88.35 \%$. The log rank test was used to compare the overall survival with the survival of the patients with and without tumor necrosis and with and without surgical margin involvement. Graph 2 compares the overall survival over 77 months (88.58\%) with the survival of the group without tumor necrosis, which was $100 \%$ over a follow-up of 69 months. Graph 3 compares the survival of this group without tumor necrosis with the survival of the group with tumor necrosis, which was $89 \%$ over a follow-up of 60 months. Graph 4 compares the overall survival (involving all the patients in the study) with the survival in the group without surgical margin involvement, which was $93.75 \%$ over a followup of 60 months. Because of the number of cases, it was also possible to compare the survival between groups with and without surgical margin involvement, over a follow-up of 30 months, as shown in Graph 5. Over this period, the survival in the group with surgical margin involvement was $80 \%$, while it was $88 \%$ in the group without surgical margin involvement. Of these, $92(30.57 \%)$ only had radiotherapy, two $(0.66 \%)$ only had chemotherapy and $20(6.64 \%)$ had both radiotherapy and chemotherapy.

Table 1. Characteristics of neoplasms from 301 Brazilian patients with cancer of the uterine cervix

\begin{tabular}{lcc}
\hline Characteristics & & $\%$ \\
\hline \multirow{3}{*}{ Histological type } & Spindle cell carcinoma & 70 \\
\cline { 2 - 3 } & Adenocarcinoma & 21 \\
\cline { 2 - 3 } & Squamous adenocarcinoma & 8 \\
\cline { 2 - 3 } Difference degree & Unknown* & 1 \\
\cline { 2 - 3 } & Modl differentiated & 18 \\
\cline { 2 - 3 } Blood invasion & Poorly differentiated & 30 \\
\hline \multirow{2}{*}{ Lymphatic invasion } & Unknown* & 42 \\
\hline \multirow{2}{*}{ Neural invasion } & Yes & 10 \\
\hline \multirow{2}{*}{ Lymph node metastasis } & No & 18 \\
\hline Compromised surgical & Yes & 82 \\
\cline { 2 - 3 } margins & No & 29 \\
\hline \multirow{2}{*}{ Necrosis } & Yes & 71 \\
& No & 27 \\
\hline
\end{tabular}

*Data not located.

Table 2. Variables with statistical significance for survival among 301 patients with cancer of the uterine cervix

\begin{tabular}{lc}
\hline Variable & Significance $(\mathrm{P})$ \\
\hline Largest tumor diameter & $\mathrm{P}<0.04$ \\
\hline Lymph node metastasis & $\mathrm{P}<0.01$ \\
\hline Presence of necrosis & $\mathrm{P}<0.05$ \\
\hline Surgical margin involvement & $\mathrm{P}<0.01$ \\
\hline
\end{tabular}

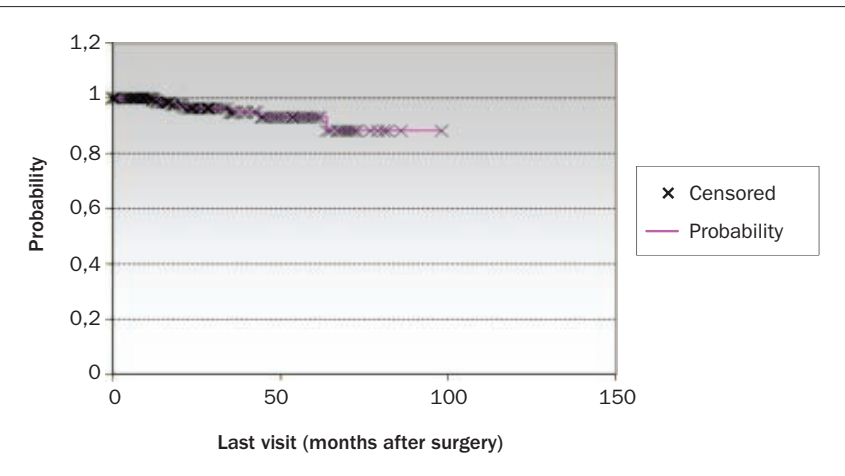

Graph 1. Overall survival of all the 301 patients in the study with a followup of 98 months, using the Kaplan-Meier method.

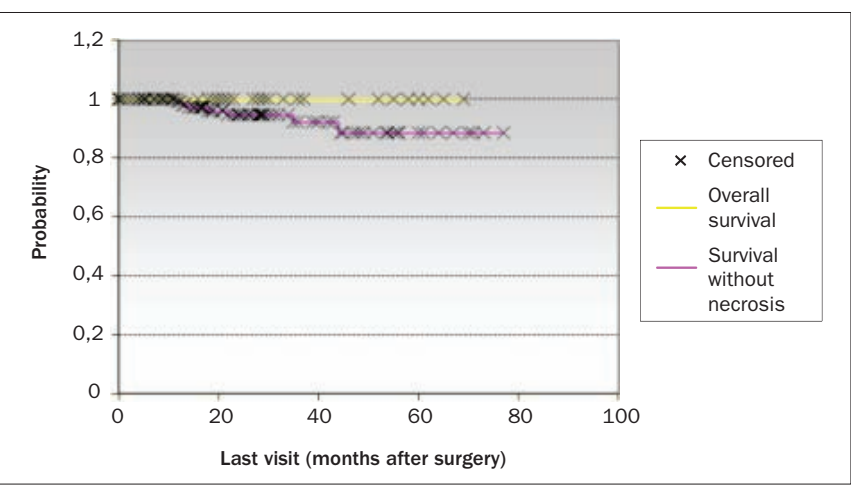

Graph 2. Overall survival of all 310 patients in the study compared with survival in the group without tumor necrosis, using the log-rank test and Kaplan-Meier method.

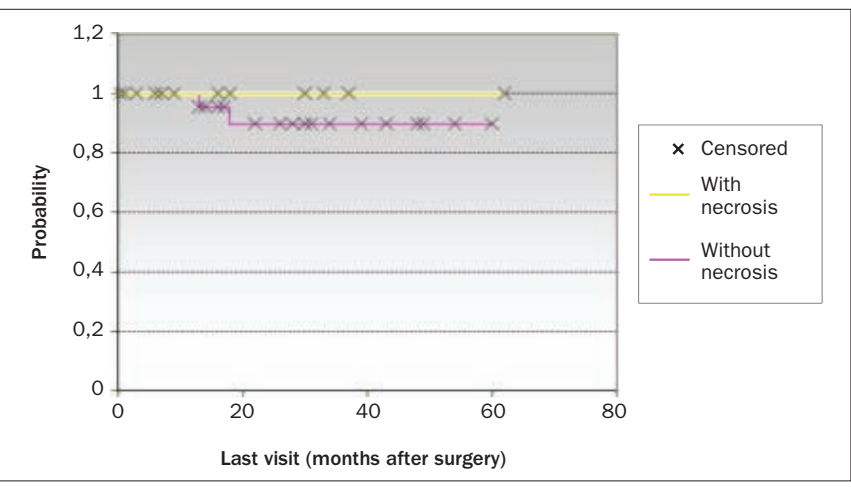

Graph 3. Survival of the groups with and without tumor necrosis, using the log-rank test and Kaplan-Meier method.

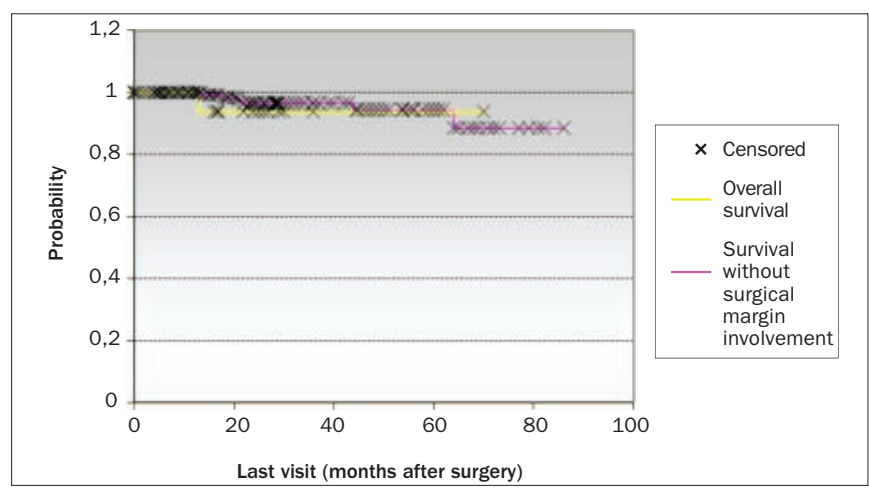

Graph 4. Overall survival of all 310 patients in the study compared with survival in the group without surgical margin involvement, using the logrank test and Kaplan-Meier method. 


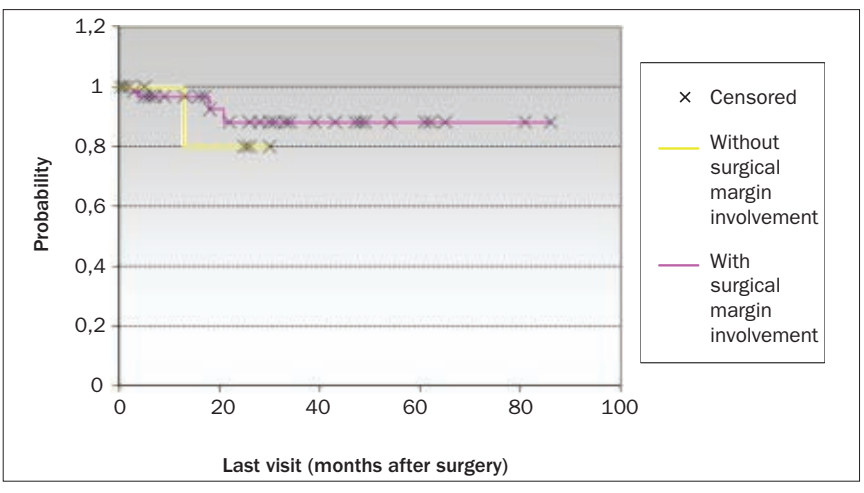

Graph 5. Survival of the groups with and without surgical margin involvement, using the log-rank test and Kaplan-Meier method.

\section{DISCUSSION}

It has already been established that many factors influence the prognosis for cervical cancer patients undergoing radical hysterectomy. Among these factors are the degree of pelvic lymph node involvement with tumor cells, the size of the tumor, vascular involvement, depth of invasion, parametrial invasion, surgical margin involvement, age, histological type and degree of tumor differentiation. ${ }^{6-9,17}$

In this study, we found that the factors influencing the survival of the patients who underwent radical hysterectomy were the presence of lymph node metastasis, tumor size and surgical margin involvement. Furthermore, we found that a variable rarely described in the medical literature was a factor influencing the patients' survival, namely the degree of necrosis on the tumor presented in the histological examination.

The presence of lymph node metastasis is the single most important prognostic factor for cervical carcinoma. ${ }^{6,8} \mathrm{It}$ is known that lymph drainage from the uterine cervix tends to go to compromised pelvic lymph nodes. Therefore, their compromised nature increases the possibility of distant pelvic metastatic relapses, while not diminishing the chances of dissemination and pelvic relapse. ${ }^{6,8} \mathrm{We}$ also found that the size of the tumor was another important influence on patients' prognoses. This gives rise to the consensus that the larger the tumor is, the worse the prognosis. ${ }^{6,89}$ Tumors smaller than $2.0 \mathrm{~cm}$ form a low-risk group, with a disease-free five-year survival rate of $95 \%$. On the other hand, tumors larger than $2.0 \mathrm{~cm}$ form a high-risk group and, in tumors larger than $4.0 \mathrm{~cm}$, the survival rate falls to $52 \%$. $^{8,9,12,15,16}$ Surgical margin involvement was another factor that influenced the patients' prognoses. In previous studies, this has been described as another very important prognostic factor. This may be because surgical margin involvement means that some tumor remains were probably not removed, which creates more possibilities of larger relapses and metastasis. ${ }^{6-9,15}$

An important finding to which our attention was drawn during the investigation was the presence of necrosis on the tumor. This was observed under the microscope, from sections stained with hematoxylineosin. This factor had a negative influence on the patients' survival. This finding has rarely been described in the literature, although data confirming that the presence of tumor necrosis is associated with lymph node metastasis do exist. ${ }^{18}$ Nevertheless, the real influence of this factor on cervical cancer patients' prognoses needs to be studied in more detail.
It is relevant to note that some factors that are often described as important prognostic factors were not statistically significant in the present investigation. Among these were the patients' ages, degree of tumor differentiation, histological type of the tumor, tumor size, blood, neural and lymphatic invasion, distance to closest margin and vaginal cuff size. This perhaps happened because of the short follow-up. However, it needs to be highlighted that the importance of lymphatic and vascular invasion is still controversial: there is evidence to corroborate the results obtained in this study, as well as the opposite. . $8-11,13,14^{-14}$

\section{CONCLUSION}

In this study, the prognostic factors that were most prevalent among patients with cervical cancer who underwent radical hysterectomy were the presence of necrosis in lymph node metastases, tumor size, surgical margin involvement and the presence of necrosis of the tumor. The first three factors have already been consolidated in the literature, but the last one is a factor that has only recently been considered important for the survival of patients undergoing this surgery.

\section{REFERENCES}

1. Novoa Vargas A, Echegollen Guzmán A. Epidemiología del cáncer de cérvix en Latinoamérica [Cervical cancer epidemiology in Latin America]. Ginecol Obstet Mex. 2001;69(6):243-6.

2. Instituto Nacional de Câncer. Estimativas da incidência e mortalidade por câncer no Brasil - 2003 [Estimative of incidence and mortality by cancer in Brazil - 2003]. Rio de Janeiro: Instituto Nacional de Câncer; 2003.

3. Parkin DM, Bray FI, Devesa SS. Cancer burden in the year 2000. The global picture. Eur J Cancer. 2001;37(Suppl 8):S4-66.

4. Brasil. Ministério da Saúde. Secretaria de Vigilância em Saúde. Sistema Nacional de Vigilância em Saúde: relatório de situação: Piauí/Ministério da Saúde, Secretaria de Vigilância em Saúde. Brasília: Ministério da Saúde; 2005. Available from: http://bvsms.saude.gov.br/ bvs/publicacoes/pi1.pdf. Accessed in 2009 (Jun 22).

5. Vieira SC, Silva AG, Vale LRG, Lima MM. Preservação dos ovários em cirurgia radical para câncer do colo uterino [Ovarian preservation in radical surgery for cervical cancer]. Rev Bras Ginecol Obstet. 2002;24(10):681-4.

6. Ho CM, Chien TY, Huang SH, Wu CJ, Shih BY, Chang SC. Multivariate analysis of the prognostic factors and outcomes in early cervical cancer patients undergoing radical hysterectomy. Gynecol Oncol. 2004;93(2):458-64.

7. Jordan LB, Monaghan H. Pathology of the cervix: recent developments. Clin Oncol (R Coll Radiol). 2004;16(4):248-54.

8. Tsai CS, Lai $\mathrm{CH}$, Wang $\mathrm{CC}$, et al. The prognostic factors for patients with early cervical cancer treated by radical hysterectomy and postoperative radiotherapy. Gynecol Oncol. 1999;75(3):328-33.

9. Kristensen GB, Abeler VM, Risberg B, Trop C, Bryne M. Tumor size, depth of invasion, and grading of the invasive tumor front are the main prognostic factors in early squamous cell cervical carcinoma. Gynecol Oncol. 1999;74(2):245-51.

10. Marchiolé P, Buénerd A, Benchaib M, Nezhat K, Dargent D, Mathevet P. Clinical significance of lympho vascular space involvement and lymph node micrometastases in early-stage cervical cancer: a retrospective case-control surgico-pathological study. Gynecol Oncol. 2005;97(3):727-32.

11. Creasman WT, Kohler MF. Is lymph vascular space involvement an independent prognostic factor in early cervical cancer? Gynecol Oncol. 2004;92(2):525-9.

12. Horn LC, Fischer U, Raptis G, Bilek K, Hentschel B. Tumor size is of prognostic value in surgically treated FIGO stage II cervical cancer. Gynecol Oncol. 2007;107(2):310-5.

13. Ayhan A, AI RA, Baykal C, Demirtas E, Ayhan A, Yüce K. Prognostic factors in FIGO stage IB cervical cancer without lymph node metastasis and the role of adjuvant radiotherapy after radical hysterectomy. Int J Gynecol Cancer. 2004;14(2):286-92.

14. Chernofsky MR, Felix JC, Muderspach LI, et al. Influence of quantity of lymph vascular space invasion on time to recurrence in women with early-stage squamous cancer of the cervix. Gynecol Oncol. 2006;100(2):288-93.

15. Horn LC, Fischer U, Raptis G, et al. Pattern of invasion is of prognostic value in surgically 
treated cervical cancer patients. Gynecol Oncol. 2006:103(3):906-11.

16. Kodama J, Seki N, Ojima Y, Nakamura K, Hongo A, Hiramatsu Y. Prognostic factors in nodepositive patients with stage IB-IIB cervical cancer treated by radical hysterectomy and pelvic lymphadenectomy. Int J Gynaecol Obstet. 2006;93(2):130-5.

17. Schmitz MJ, Nahhas WA, Clark MA, Brown M. Stage IB carcinoma of the cervix: are all staging tests and procedures necessary? Eur J Gynaecol Oncol. 1994;15(3):199-204.

18. Fregnani JHTG, Soares FA, Novik PR, Lopes A, Latorre MRDO. Fatores de risco não habituais para metástase linfonodal no câncer do colo do útero [Unusual risk factors for lymph node metastasis in cancer of the uterine cervix]. Rev Assoc Med Bras (1992). 2007;53(4):338-43.

Place where the paper was presented: 52nd Brazilian Congress of Gynecology and Obstetrics, Fortaleza, Ceará, Brazil, November 13 to 17, 2007
Sources of funding: Not declared Conflict of interest: None

Date of first submission: February 27, 2008

Last received: July 14, 2009

Accepted: August 6, 2009

Address for correspondence:

Sabas Carlos Vieira

Rua Félix Pacheco, 2.159 - Sala 305

Centro - Teresina (PI) - Brasil

CEP 64001-160

Tel./Fax. (+55 86) 3226-1555

E-mail: sabas.vieira@uol.com.br 